\title{
Review of the Oriental Azelia Robineau-Desvoidy, 1830 (Diptera: Muscidae)
}

\section{Обзор ориентальных видов Azelia Robineau-Desvoidy, 1830 (Diptera: Muscidae)}

\author{
N.E. Vikhrev \\ H.E. Вuxpeв
}

\begin{abstract}
Zoological Museum of Moscow University, Bolshaya Nikitskaya 6, Moscow 125009, Russia. E-mail: nikita6510@ya.ru Зоологический музей, Московский государственный университет им. М.В. Ломоносова, Большая Никитская ул., 6, Москва 125009, Россия
\end{abstract}

KEYWORDS: Azelia beuki, Azelia plumitibia, Diptera, Muscidae, Oriental region, new species, key

КЛЮЧЕВЫЕ СЛОВА: Azelia beuki, Azelia plumitibia, Diptera, Muscidae, Ориентальная область, новый вид, ключ

ABSTRACT. Two new species of Azelia are added to the single species $A$. nuditibia Emden, 1965 previously known for the Oriental region: A. plumitibia Feng, Fan \& Zeng, 1999 and $A$. beuki sp.n. described here. New distribution records, taxonomic notes and identification key for Oriental Azelia and related Palaearctic species are given.

РЕЗЮМЕ. Два новых вида Azelia (A. plumitibia Feng, Fan \& Zeng, 1999 и описанная в данной статье A. beuki sp.n. ) приведены для Ориентальной области, для которой была ранее известен только $A$. nuditibia Emden, 1965. Приведены новые данные по распространению и таксономии, а также ключ для определения Ориентальных и родственных Палеарктических видов Azelia.

\section{Introduction}

Genus Azelia Robineau-Desvoidy, 1830 is mostly represented in temperate areas of the Holarctic, only few species are known from tropical regions. Species of Azelia are associated with dung, usually of large herbivorous animals. Such animals became rare in the wild, so are becoming their domesticated relatives grazing free. This circumstance, together with a small size and inconspicuous coloration make Azelia rather uncommon in collections.

So far only Azelia nuditibia Emden, 1965 was known for the Oriental region. In this paper, I would like to add two more species: A. plumitibia Feng, Fan et Zeng, 1999 and $A$. beuki sp.n. and to discuss the taxonomic issues concerning Oriental Azelia. In some species of Azelia the females are unknown, in other species identification of females seems to me doubtful, for this reason in the present paper I decided to restrict myself in most cases to males only.

\section{Material and methods}

The specimens studied are in the Zoological Museum of Moscow University, that is not indicated in text below.

The following abbreviations for morphological structures are used: $f 1, t 1, f 2, t 2, f 3, t 3=$ fore-, mid-, hindfemur or tibia; $a c=$ acrostichal setae; $d c=$ dorsocentral setae; $a, p, d, v=$ anterior, posterior, dorsal, ventral seta(e); prst - presutural, post - postsutural.

The abbreviation for the tarsi as tar followed by a pair of digits separated by a hyphen: the first digit (1 to 3 ) gives the leg number and the second digit (1 to 5 ) the number of the tarsal segment. For example, $\operatorname{tar} 1-4=4-$ th segment of fore tarsus; tar3-1 = hind basitarsus [Vikhrev, 2011].

Geographical coordinates are given in Decimal Degrees format.

\section{Examined material and taxonomic notes}

\section{Azelia beuki Vikhrev sp.n.}

Figs 1-5.

MATERIAL. Holotype: $\sigma^{\top}$, Thailand, Phang Nga prov., Khao Lak env., $8.712^{\circ} \mathrm{N} 98.254^{\circ} \mathrm{E}$, near elephant camp, 16-21.XII.2011, N.Vikhrev. Paratypes: $10^{\top}, 2 \circ 0$, India, Goa state, Sahakari spice farm, $15.408^{\circ} \mathrm{N} 74.024^{\circ} \mathrm{E}, 22 . I .2008$, N.Vikhrev; Thailand: $45 \mathrm{O}^{7} \mathrm{O}^{7}$, 44 오, Phang Nga prov., Khao Lak env., $8.616^{\circ} \mathrm{N} 98.245^{\circ} \mathrm{E}, 8.712^{\circ} \mathrm{N}$ $98.254^{\circ} \mathrm{E}, 8.760^{\circ} \mathrm{N} 98.284^{\circ} \mathrm{E}$ and $8.840^{\circ} \mathrm{N} 98.474^{\circ} \mathrm{E}$, near elephant camps, 14-24.XII.2009-2010, N.Vikhrev; $3 \sigma^{\top} \sigma^{7}, 10$, 9 , , Mae Hong Son prov., Pai env., $19.31^{\circ} \mathrm{N} 98.46^{\circ} \mathrm{E}$, on elephant dung, $15-20 . X I$. 2010, N.Vikhrev.

The holotype and most paratypes are in the Zoological Museum of Moscow University, $3 \sigma^{\top} \sigma^{\top}$ and 3 + 9 paratypes are in the Natural History Museum, London.

DESCRIPTION. Male. Dark, densely grey dusted species with partly yellowish legs, body size $2.5 \mathrm{~mm}$.

Head with big contiguous bare eyes, anterior facets strongly enlarged. Narrow brown fronto-orbital plates touching, 
frontal vitta visible only in anterior third of frons. A pair of inclinate setae present on anterior part of frons (other setae reduced to minute hairs which are completely broken in vast majority of specimens). Parafacials linear, subshining; gena about half as wide as antenna. Palpi and antennae black, aristal hairs as long as basal diameter of arista.

Thorax with scutum and pleura densely grey dusted except (in lateral view) for anterior part of scutum from neck to level of anterior post $d c$ and basal 2/3 of scutellum, which are math black.

Dorsocentrals $2+3$, presutural acrostichals in 4 regular rows, katepisternal $1+1$. Wings hyaline, calypters brownish, halter pale yellow with brown tip of knob.

Legs of somewhat uncertain colour: femora and tarsi usually yellowish brown, tibiae dirty yellow. $f 1$ with a row of 5 long $p v$ setae and a row of shorter $p d ; f 2$ with a submedian $v$-seta, $a d$ seta in basal $1 / 3$ and $2 p d$ preapicals; $f 3$ with 1(2) $a v$ seta(e) at apex, a row of $a d$ setae and $1 p d$ preapical. $t 1$ with $d$ preapica; $t 2$ with submedian $p$-seta; $t 3$ with $1 a v$ and $1 a d$ setae beyond middle. Fore tarsus modified like in $A$. monodactyla Loew, 1874: $\operatorname{tar} 1-4$ with a pair of $d$-setae and with several setulae at apex, outer claw elongate and dilated apically.

Abdomen slightly translucent yellowish at base, otherwise densely yellowish-grey dusted. Median vitta, interrupted at posterior half of tergites, present on tergites $1+2$ to 4 , but usually hardly distinct at tergite 4; small paired lateral spots present at tergites 2 and 3 . Male terminalia shown on Figs 3-4.

Female differs from male as follows:

Eyes with anterior facets not enlarged. Frons wide, about $1 / 3$ of head width; interfrontalia with a pair of cruciate interfrontal setae (Fig. 5), interfrontalia blackish but frontal triangle and areas around interfrontal setae densely yellowish-grey dusted. Fronto-orbital plate grey dusted, in addition to inclinate setae with 1 proclinate and 2 reclinate setae. Parafacial wider, distinctly shining in upper part (Fig. 5). Thorax evenly brownish-grey dusted. Legs dark, fore tarsus not modified, $f 2$ without submedian $v$-seta but with preapical $a$-seta. Abdomen not yellowish at base, dusting of abdomen brownish-grey.

DIAGNOSIS. A. beuki sp.n. is distinctly related to the Palaearctic A. monodactyla, males of both species have similar modifications of the fore tarsus, their ecology is also alike. The differences between males are given here in the identification key.

Female. Based on my own experience I have an opinion that identification of females of the Palaearctic Azelia (with the exception of more or less reliably separated $A$. nebulosa and $A$. cilipes (Haliday, 1838)) is at least doubtful with the use of available keys offered by Fonseca [1968] or Gregor et al. [2002]. But female A. beuki sp.n. may be reliably separated at least from other known females of the Oriental Azelia due to the set of atypical characters. Here I offer the preliminary key for females of Azelia species mentioned in the present paper.

ETYMOLOGY. The new species is named after Dr. Paul Beuk (The Netherlands), the founder of the site www.diptera.info.

ECOLOGY. All specimens of A. beuki sp.n. were collected on or around elephant dung near so-called "elephant camps" - the sites for elephant riding allegedly in jungle, but usually among secondary vegetation like abandoned $\mathrm{He}$ vea plantations. Alike A. monodactyla and in contrast with most other species, $A$. beuki sp.n. does not avoid direct sun light.
Identification key for Oriental Azelia. Females.

1. Body size more than $4 \mathrm{~mm}$. Tibiae more or less reddish. ..... nebulosa Robineau-Desvoidy

(and probably plumitibia Feng, Fan \& Zeng)

- Body size less than $4 \mathrm{~mm}$. Tibiae black. ........................ 2

2. Presutural $a c$ in 4 regular rows. Frons with areas around insertion of interfrontal setae densely dusted. Inner surface of upper parafacial with a narrow shining black stripe (Fig. 3) beuki sp.n.

- Presutural $a c$ in 2 rows. Areas around insertion of interfrontal seta concolorate to the rest of frons. Parafacial evenly whitish-grey dusted (Fig. 4).

3. Black spots on abdomen large. .................. nuditibia Emden — Black spots on abdomen small. ....... monodactyla Loew

\section{Azelia nuditibia Emden, 1965}

Azelia nuditibia Emden, 1965: 331.

MATERIAL. Vietnam: Lai Chau prov., Sapa env., $\left(22.34^{\circ} \mathrm{N}\right.$ 103.85 $\left.{ }^{\circ} \mathrm{E}\right), 1500 \mathrm{~m}$ asl, 05.IV.2011, A.Ozerov, 2 우.

REMARKS. I had not examined myself the type material (collected from N. Myanmar, Kambaiti, 2000m asl) but chaetotaxy of the legs and thorax given in the detailed original description was kindly confirmed by A.C. Pont [pers. comm.]. Still the differences of this species from the Palaearctic Azelia triquetra (Wiedemann, 1817), mentioned by Emden [1965] as related species is uncertain for me. Also the records of A. nuditibia from S. India (Karnataka and Tamil Nadu states) given by Shinonaga \& Tewari [2008] to my opinion requires verification, for at my experience $A$. nuditibia was reliably known only from the mountain areas in the northern part of the Oriental region and in spring time, the specimens of Azelia collected from lower altitude and hotter areas were always $A$. beuki sp.n. I have 2 female specimens from N. Vietnam preliminary identified as A. nuditibia. These females entirely fit Emden's description, distinctly differ from $A$. beuki sp.n. and also differing from females of $A$. monodactyla (see the key for females in Diagnosis for $A$. beuki sp.n.). Anyway, more material is necessary to clarify the taxonomical status of $A$. nuditibia Emden.

\section{Azelia plumitibia Feng, Fan \& Zeng, 1999}

Azelia plumitibia Feng, Fan \& Zeng, 1999: 323.

MATERIAL. $\sigma^{\top}$, Russia, Amur reg., Zeya env., $\approx 53.7^{\circ} \mathrm{N} 127.3^{\circ} \mathrm{E}$, 24.VI.1982, A.Ozerov; $\sigma^{7}$, Vietnam, Lai Chau prov., road to Mt. Fansipan, $2095 \mathrm{~m}$ asl, $22.336^{\circ} \mathrm{N} 103.784^{\circ} \mathrm{E}, 04 . \mathrm{IV} .2011$, A. Medvedev.

REMARKS. Information about this species available in English is very scarce: "... hind tibia on $a d$ and $p v$ surfaces each with a row of long-thin bristles respectively appearing to be plume-like in profile; male cerci without a pair of subtriangular processes lateral by in posterior view; surstyli broadened and blunt apically in lateral view. ㅇ: Unknown. Holotype $\sigma^{\gamma}$, Mianyang (Mt. Fule, 600m, 314ㅗN, 104²22E), Sichuan Prov., 27, Jun., 1981, taken by Zeng Wenzhao; paratype $2 \sigma^{7} \sigma^{7}$, Yaan (Mt. Laoban, 700m, 29592N, 102 $572 \mathrm{E}$ ), Sichuan Prov., 8, 14, April, 1989, taken by Feng Yan" [Fan et al., 1999: 321]. The description of the hind tibia (and the drawing too) is similar to that of Azelia nebulosa R-D (the ad row on $t 3$ is present also in the Holarctic $A$. cilipes (Haliday, 1838), but in this case the $p v$ row is absent). A. nebulosa is not listed among species recorded for China [Xue \& Chao, 1998], no difference between $A$. plumitibia and $A$. nebulosa was given [Fan et al., 1999]. The material collected from N. Vietnam and Amur region of Russia somewhat clarified the situation.

To begin with the ecozone: the type locality of $A$. plumitib$i a$ is Sichuan province of China, it might be regarded as either 
the Palaearctic or Oriental region, but Vietnam distinctly belongs to the Oriental region and Russia is the Palaearctic. Examined specimens of $A$. plumitibia are really similar to $A$. nebulosa in most characters: $t 3$ with $6-9$ strong and long (at least 2 time as long as the tibia width) $a v$ setae; tar $2-3$ ventrally with rather long waved fine hair; abdominal tergites with large spots partly fused with each other or almost so. But both examined specimens have strong $p$ seta on $t 2$, this seta is typical for $A$. cilipes but never found among 50 examined specimens of $A$. nebulosa from several distant locations (see material listed for $A$. nebulosa). Note also that there is a gap between the natural distributions of $A$. nebulosa and A. plumit$i b i a$, the first one was never recorded from Siberia [Sorokina \& Pont, 2010] and the easternmost known locality is so far Azerbaijan. Considering all this I regard A. plumitibia as a valid species though very closely related to $A$. nebulosa.

The following two species are not recorded for the Oriental region, but I list the examined material for several reasons. First, A. nebulosa is closely related to the Oriental A. plumitibia and A. modactyla is related to A. beuki sp.n.. Second, the records of A. nebulosa for Azerbaijan and of A. modactyla for Turkey are the new country records. What is more, A. monodactyla was known from several European contries and from the Far East (NE China and Japan), but was never recorded from Russia, so Russia is also a new country record with 3 new regional records inside Russia. Even such a common species as A. nebulosa was formally recorded for Russia only from St.-Petersburg region [Hennig, 1960; Pont, 1986]. Third, the records of A. monodactyla in S Turkey and A. nebulosa in S Azerbaijan show that these species may possibly penetrate into the Oriental region.

\section{Azelia monodactyla Loew, 1874}

Azelia monodactyla Loew, 1874: 34

MATERIAL. Russia: $\sigma^{7}$, Astrakhan reg., Baskunchak salt-lake, $48.19^{\circ} \mathrm{N} 46.82^{\circ} \mathrm{E}, 2-4 . V .2010$, K.Tomkovich ; $150^{7} \sigma^{7}$, Krasnodarsky Kray, Sochi distr., Adler env., 19.IV-25.VI.2008-11, N.Vikhrev; $2 \mathrm{O}^{7} \mathrm{O}^{7}$, Adygeya, $44.001^{\circ} \mathrm{N} 40.133^{\circ} \mathrm{E}, 700 \mathrm{~m}$ asl, N.Vikhrev, 28.VI.2011; $4 \mathrm{O}^{\mathrm{T}}{\mathrm{O}^{\top}}^{\mathrm{T}}$, Moscow reg., Strogino, $55.784^{\circ} \mathrm{N} 37.403^{\circ} \mathrm{E}$, 19.IV.2011; $0^{7}$, Turkey: Antalya prov., Titreyen L., $36.754^{\circ} \mathrm{N}$ $31.457^{\circ} \mathrm{E}, 01 . \mathrm{VI} .2008$, N.Vikhrev.

REMARKS. Gregor et al. [2002] characterised A. monodactyla as a relatively rare Eurasian species. At my opinion this species is not rare but distinctly associated with horse dung and prefers rather dry and sunny sites in contrast to most other Azelia species which like wet and shady conditions.

Azelia nebulosa Robineau-Desvoidy, 1830

Azelia nebulosa Robineau-Desvoidy, 1830: 592.

Atomogaster macquarti Staeger in Schiødte, 1843: 319.

MATERIAL. $\sigma^{\top}$, Azerbaijan, Lankaran reg., $38.66^{\circ} \mathrm{N} 48.78^{\circ} \mathrm{E}$, 27.X.2008, N.Vikhrev; $\sigma^{7}$, France, Haute-Normandie reg.; Russia: $2 \sigma^{7} \sigma^{7}$, Ivanovo reg., Ivanovo env.; $36 \bigcirc^{7} \sigma^{7}$, Krasnodarsky Kray, Sochi district and Adygeya (from sea level to 2000m asl); $7 \mathrm{O}^{7} \sigma^{7}$, Moscow reg; $0^{\top}$, Ukraine: Ivano-Frankivsk reg.
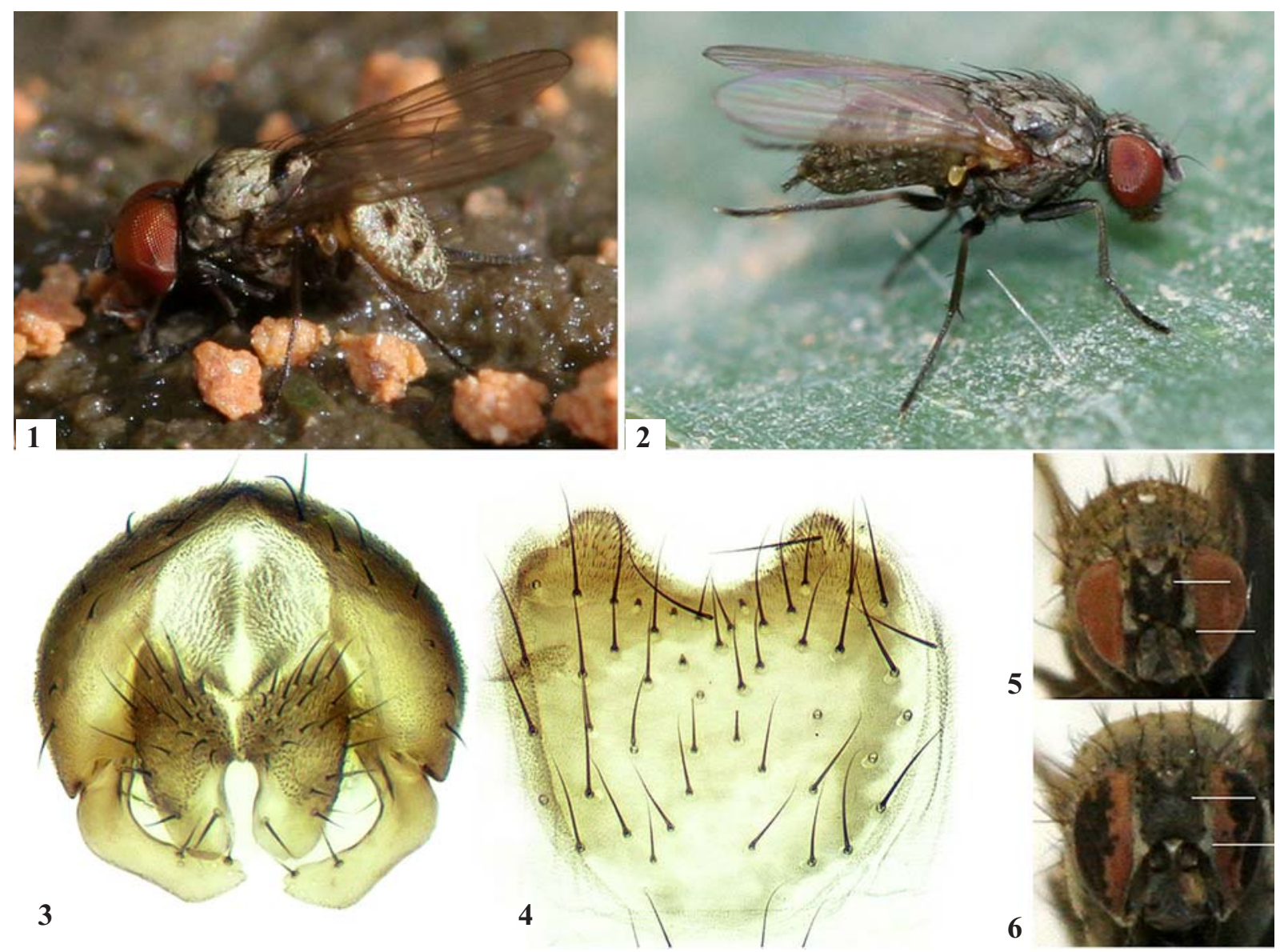

Figs 1-6. Azelia spp.: 1-5 - Azelia beuki sp.n.; 6 - A. monodactyla Loew; 1-2 - habitus; 3 - cerci and surstyli; 4 - sternite 5; 56-head; 1, 3-4 - male; 2, 5-6 - female; $1-2$ - lateral view; 3-4 - dorsal view; 5-6- frontal view.

Рис. 1-6. Azelia spp.: 1-5 - Azelia beuki sp.n.; 6-A. monodactyla Loew; 1-2 - внешний вид; 3 - церки и сурстили; 4 - стернит 5; 5-6- голова; 1, 3-4 - самец; 2, 5-6- самка; 1-2 - сбоку; 3-4- сверху; 5-6- спереди. 
Identification Key for Oriental Azelia. Males.

(A. monodactyla and A. nebulosa are recorded only for Palaearctic)

1. Hind tibia with rows of long setae on $a d-d$, $a v$ and $p v$ surfaces.

- Hind tibia with single setae at most.

2. $t 2$ with a strong submedian $p$-seta. plumitibia Feng, Fan \& Zeng

- $t 2$ without submedian $p$-seta. (nebulosa Robineau-Desvoidy)

3. $t 2$ without submedian $p$-seta, outer claw of fore tarsus no modifaied, $t 3$ with $2 a v$ setae and without $a d$,pstr $a c$ in 2 rows. nuditibia Emden

- $t 2$ with submedian $p$-seta, outer claw of fore tarsus elongate and dilated apically.

4. prst $a c$ in 2 rows, more widely separated from $d c$ than from each other. Anterior facets of eyes only slightly enlarged. tar $1-4$ with 2 strong spine-like setae, these setae distinctly longer than width of tarsomer. Tibiae dark. $t 3$ with 1(2) $a v$ without ad. Abdomen dark. "Azelia-spots" (paired rounded lateral spots and interrupted median vitta) present on tergites 3 to 5 . Body size $2.5-3 \mathrm{~mm}$............. (monodactyla Loew)

- prst ac in 4 rows,more widely separated from each other than from $d c$. Anterior facets of eyes distinctly enlarged. tarl4 with only 2 weak setae which are shorter than width of tarsomer. Tibiae yellowish. $t 3$ with 1 av and $1 \mathrm{ad}$. Abdomen yellowish at least at base. "Azelia-spots" partly reduced: present but small on tergite 3 and 4 , absent on tergite 5 . Body size $2.5 \mathrm{~mm}$. beuki sp.n.

ACKNOWLEDGEMENTS. I thank for their kind help Oleg Kosterin (Novosibirsk), Andrey Ozerov (Moscow) and Adrian Pont (Oxford).

\section{References}

Emden F.I. 1965. Diptera. Vol.7. Muscidae. Pt.1// R.B.S. Sewell \& M.L. Roonwal (eds.). The fauna of India and the adjacent countries.Delhi: Government of India. xiv +647 p.

Feng Y., Fan Z. \& Zeng W. 1999. Three New Species of Calyptratae from Sichuan, China (Diptera: Anthomyiidae, Muscidae) // Chines Journal of Vector Biology and Control. Vol.10. No.5. P.321-324.

d'Assis-Fonseca E.C.M. 1968. Diptera Cyclorrhapha Calyptrata, Muscidae // Handbook for the Identification of British Insects. London: Royal Entomological Society. Vol.10. No.4(b). 118 p.

Gregor F., Rozkošny R., Barták M. \& Vaňhara J. 2002. The Muscidae (Diptera) of Central Europe // Folia Facultatis Scientiarum Naturalium Universitatis Masarykianae Brunensis, Biologia. Vol.107. 280 p.

Hennig W. 1955-1964. Family Muscidae // E. Lindner (ed.). Die Fliegen der Palaarktischen Region. Stuttgart: Schweizerbart. Lfg.63b. $1110 \mathrm{~S}$.

Pont A.C. 1986. Family Muscidae // Á. Soós \& L. Papp (eds.). Catalogue of Palaearctic Diptera. Scathophagidae-Hypodermatidae. Vol.11. 312 p. Budapest: Akadémiai Kiadó \& Amsterdam: Elsevier Science Publishers B.V.P.57-215.

Shinonaga S. \& Tewari R.R. 2008. Record of the Muscid flies collected in India, Sri Lanka and Bangladesh (Diptera, Muscidae) // Japanese Journal of Systematic Entomology. Vol.14. No.2. P.205-251.

Sorokina V. \& Pont A.C. 2010. An annotated catalogue of the Muscidae (Diptera) of Siberia // Zootaxa. Vol.2597. P.1-87.

Vikhrev N. 2011. Review of the Palaearctic members of the Lispe tentaculata species-group (Diptera, Muscidae): revised key, synonymy and notes on ecology // ZooKeys. Vol.84. P.59-70.

Xue W-Q. \& Chao C-M. 1998. Flies of China. Vol.1. Shenyang: Liaoning Science and Technology Press. 1365 p. [In Chinese]. 